ISSN: 1978-7057

\title{
PENGARUH FAKTOR-FAKTOR PRODUKSI TERHADAP PENDAPATAN PETANI TANAMAN HIAS DI DESA BANGUN SARI KECAMATAN TANJUNG MORAWA KABUPATEN DELI SERDANG
}

\author{
Ratna Dulika Siregar \\ Alumni Jurusan Manajemen Fakultas Ekonomi Universitas Negeri Medan \\ Ahmad Hidayat \\ Dosen Jurusan Manajemen Fakultas Ekonomi Universitas Negeri Medan
}

\begin{abstract}
Abstrak
Penelitian ini bertujuan untuk mengetahui seberapa besar pengaruh faktor produksi lahan, tenaga kerja dan modal terhadap pendapatan petani tanaman hias di Desa Bangun Sari Kecamatan Tanjung Morawa Kabupaten Deli Serdang dan untuk mengetahui faktor produksi mana yang paling signifikan berpengaruh terhadap pendapatan petani tanaman hias di Desa Bangun Sari Kecamatan Tanjung Morawa Kabupaten Deli Serdang. Populasi dalam penelitian ini adalah seluruh petani tanaman hias di Desa Bangun Sari sebanyak 235 orang dengan jumlah sampel 70 orang. Teknik pengumpulan data yang digunakan adalah dengan menggunakan kuesioner. Berdasarkan hasil penelitian melalui uji validitas dari setiap soal pertanyaan adalah valid. Teknik analisis data adalah menggunakan analisis jalur. Hasil ini menunjukkan bahwa ada pengaruh faktor lahan, tenaga kerja dan modal terhadap pendapatan petani tanaman hias di Desa Bangun Sari Kecamatan Tanjung Morawa Kabupaten Deli Serdang. Dalam pengujian hipotesis dengan menggunakan rumus uji $F$ dan uji $T$. Dengan demikian hipotesis dalam penelitian ini yang diajukan sebelumnya diterima.
\end{abstract}

Kata Kunci: Lahan, Tenaga Kerja, Modal dan Pendapatan

\section{PENDAHULUAN}

Tanaman hias merupakan salah satu komoditas holtikultura yang mempunyai nilai ekonomi cukup tinggi, sehingga prospeknya sangat cerah untuk dijadikan bisnis atau peluang usaha yang menjanjikan. Baik dari segi permintaan maupun harga jualnya juga sangat tinggi. Berkembangnya kegiatan usaha tanaman hias di dalam negeri berhubungan dengan meningkatnya pendapatan konsumen, tuntutan keindahan lingkungan, pembangunan industri pariwisata, serta pembangunan komplek perumahan, perhotelan dan perkantoran.

Desa Bangun Sari merupakan salah satu daerah penghasil tanaman hias yang potensial di Sumatera
Utara, khususnya Kecamatan Tanjung Morawa Kabupaten Deli Serdang. Jenis tanaman hias yang terdapat di desa Bangun Sari adalah bonsai, pucuk merah, mawar, melati, anthurium, palem, anggrek, bougainville, asoka, cemara, kamboja, kroket merah, tricolor, balik angin dan lain-lain. Usaha tanaman hias ini merupakan sumber pendapatan utama bagi masyarakat setempat, karena sebagaian besar penduduknya bermata pencarian sebagai petani tanaman hias. Usaha tanaman hias ini memang dapat memberikan keuntungan yang besar bagi para petaninya. Namun, tidak semua petani tanaman hias merasa bahwa dari usaha tanaman hiasnya tersebut mereka mampu untuk memenuhi 
kebutuhan hidupnya sehari-hari. Hal ini disebabkan jumlah petani tanaman hias di daerah tersebut cukup banyak, sehingga persaingan diantara para petani sangat ketat dan pendapatan petani relatif rendah.

Tabel 1. Jumlah Pendapatan Petani

Tanaman Hias Di Desa Bangun Sari

\begin{tabular}{|c|c|c|c|}
\hline No & $\begin{array}{c}\text { Jumlah } \\
\text { Pendapatan }\end{array}$ & Frekuensi & Persen \\
\hline 1 & $\begin{array}{c}<\mathrm{Rp} \\
2.000 .000\end{array}$ & 31 & $44 \%$ \\
\hline 2 & $\begin{array}{c}\mathrm{Rp} \\
2.000 .000- \\
\mathrm{Rp} \\
4.999 .000\end{array}$ & 23 & $33 \%$ \\
\hline 3 & $\begin{array}{c}\mathrm{Rp} \\
5.000 .000- \\
\mathrm{Rp} \\
9.999 .000\end{array}$ & 10 & $14 \%$ \\
\hline 4 & $\begin{array}{c}>\mathrm{Rp} \\
10.000 .000\end{array}$ & 6 & $9 \%$ \\
\hline \multicolumn{2}{|r|}{ Jumlah } & 70 & $100 \%$ \\
\hline
\end{tabular}

Sumber: Hasil Pengolahan Data 2014

Berdasarkan tabel diatas, terlihat bahwa sebagian besar pendapatan petani masih dibawah Rp 2.000 .000 /bulan. Pada saat ini, jumlah tersebut tentu tidak cukup untuk memenuhi kebutuhan seharihari, seperti : kebutuhan rumah tangga (pangan), biaya sekolah anakanak dan lain-lain. Apabila hal ini terjadi secara terus menerus, maka akan menimbulkan masalah bagi petani. Oleh karena itu, perlu dilakukan penelitian terhadap faktorfaktor produksi yang mempengaruhi pendapatan petani, diantaranya yaitu faktor- lahan, tenaga kerja dan modal.

Pada umumnya lahan yang digunakan petani untuk usaha tanaman hias adalah pekarangan rumah atau menyewa lahan milik orang lain. Namun, banyaknya produksi tanaman hias yang dihasilkan oleh masing-masing petani tidak didukung dengan luas lahan yang tersedia. Petani merasa kesulitan untuk menata tanaman hiasnya, sehingga banyak petani yang meletakkan tanaman hiasnya sampai ke tepi jalan perlintasan kenderaan. Upaya yang dilakukan petani dalam mengatasi keterbatasan lahannya adalah dengan membangun beberapa rak ataupun naungan yang berisikan rak-rak bibit bunga. Para petani yang memiliki luas lahan yang terbatas umumnya melakukan kegiatan pembuatan rak-rak tersebut. Karena untuk memperluas lahan mereka terhambat oleh masalah permodalan. Luas lahan petani yang sempit tidak dapat dijadikan jaminan untuk melakukan pinjaman kredit ke bank atau lembaga keuangan lainnya.

Selain lahan yang sempit, petani tanaman hias di Desa Bangun Sari juga mengalami masalah tenaga kerja yang digunakan pada usahataninya. Kebanyakan tenaga kerja usaha tanaman hias adalah tenaga kerja dari dalam keluarga (anggota keluarga), hal ini dikarenakan luas lahan petani yang sempit sehingga para petani tanaman hias tidak begitu memerlukan tenaga kerja upahan. Selain itu, untuk menyewa tenaga kerja dari luar (tenaga kerja upahan), petani juga merasa kesulitan jika harus mengurangi pendapatan mereka untuk membayar upah tenaga kerja tersebut. Akan tetapi, jika pada waktu tertentu terjadi kekurangan tenaga kerja dari dalam keluarga maka digunakan tenaga kerja upahan dan hal ini hanya terjadi pada petani yang memiliki lahan lebih luas. Selain itu, untuk meningkatkan produktivitas dari usahanya juga masih terhambat dikarenakan masih banyak diantara 
tenaga kerja tersebut adalah ibu-ibu atau anak-anak, yang tenaganya tergolong lemah, sehingga produktivitas yang diharapkan tidak dapat tercapai. Selain itu, pengetahuan petani juga sangat terbatas. Hal ini dikarenakan pendidikan yang dicapai petani masih tergolong rendah, sehingga petani tidak mengetahui bagaimana cara menggunakan teknologi terbaru untuk mengelola atau mengembangkan usaha tanaman hiasnya.

Setiap usaha yang dijalani akan selalu memerlukan modal untuk dapat bertahan selama usaha tersebut berjalan. Sementara itu, petani tanaman hias di Desa Bangun Sari tidak memiliki modal yang cukup besar untuk mengembangkan usaha tanaman hiasnya. Sempitnya luas lahan yang dimiliki membuat petani sulit untuk memperoleh pinjaman atau kredit, hal ini dikarenakan luas lahan tersebut tidak dapat dijadikan jaminan atau meyakinkan pihak yang memberikan pinjaman bahwa petani mampu untuk mengembalikan uang yang dipinjamnya tersebut pada waktu yang ditentukan. Dengan kondisi tersebut, muncullah sekelompok orang-orang yang menawarkan pinjaman dengan syaratsyarat yang mudah, proses yang cepat, namun dengan bunga yang tinggi. Oleh karena itu, banyak diantara petani yang menggunakan jasa rentenir untuk memperoleh modal demi mengembangkan usaha tanaman hiasnya, tanpa petani sadari bahwa dengan bunga yang tinggi tersebut akan semakin menyengsarakan petani. Pada akhirnya petani akan dirugikan dan banyak diantara petani yang menyerahkan usaha tanaman hiasnya pada rentenir karena tidak sanggup untuk melunasi utang-utangnya. Sehingga keinginan petani untuk mengembangkan usaha tanaman hiasnya akan terhambat atau bahkan mengalami kebangkrutan.

Selain itu, upaya penyuluhan yang tidak pernah dilakukan oleh pemerintah daerah setempat juga merupakan masalah yang perlu diperhatikan. Petani mengaharapkan adanya campur tangan atau perhatian dari pemerintah setempat untuk mengadakan kegiatan penyuluhan untuk mengembangkan usaha tanaman hias petani. Tujuannya adalah petani dapat meningkatkan hasil produksi tanaman hiasnya, dengan demikian pendapatan petani juga akan meningkat.

Produksi tanaman hias mencapai 2.166.000 unit pada tahun 2009 meningkat menjadi 3.830 .000 unit pada tahun 2010, menurun kembali pada tahun 2011 menjadi 2.131.000 unit dan pada tahun 2012 meningkat menjadi 3.038 .000 unit. Adanya fluktuasi produksi tersebut tidak terlepas dari pengaruh faktorfaktor produksi yang digunakan petani pada usahataninya.

\section{METODE PENELITIAN \\ Waktu dan Lokasi Penelitian}

Penelitian ini dilaksanakan pada bulan Maret 2014 pada petani tanaman hias di Desa Bangun Sari Kecamatan Tanjung Morawa Kabupaten Deli Serdang.

\section{Populasi dan Sampel}

Populasi dalam penelitian ini adalah seluruh jumlah petani tanaman hias yang ada di Desa Bangun Sari Kecamatan Tanjung Morawa Kabupaten Deli Serdang sebanyak 
ISSN: 1978-7057

235 petani (Monografi Desa Bangun Sari, 2013).

Semakin besar variasi suatu populasi maka semakin besar pula ukuran sampel yang diperlukan agar estimasi terhadap parameter populasi dapat dilakukan dengan akurat dan presisi. Selanjutnya Riduwan (2006) menyebutkan sampel adalah bagian dari populasi yang mempunyai ciri ciri atau keadaan tertentu yang akan diteliti. Dalam penelitian ini pengambilan jumlah sampel dengan menggunakan rumus (Riduwan, 2006).

$$
\mathrm{n}=\frac{\mathrm{N}}{\mathrm{N} \cdot \mathrm{d}^{2+1}}
$$

Di mana $: \mathrm{n}=$ jumlah sampel $\mathrm{N}=$ jumlah populasi $\mathrm{d}^{2}=$ presisi yang

ditetapkan

Pada penelitian ini tingkat ketelitian atau keyakinan yang dikehendaki adalah $90 \%$ atau dengan tingkat presisi yang diharapkan 10\% atas dasar pertimbangan bahwa untuk penelitian sosial tingkat kesalahan masih dapat ditolerir sampai dengan $10 \%$. Jumlah petani tanaman hias yang ada di Desa Bangun Sari Kecamatan Tanjung Morawa sebanyak 235 orang. Sampel yang diperoleh dengan mempergunakan rumus di atas dari populasi $(\mathrm{N})$ sebanyak $=235$ orang petani tanaman hias adalah sebesar 70 orang. Jumlah sampel sebesar 70 orang tersebut diambil secara proportional random sampling sesuai dengan strata luas lahan tanaman yang diusahakan.

\section{Variabel Penelitian dan Defenisi Operasional Variabel penelitian}

Variabel adalah obyek penelitian atau apa yang menjadi titik perhatian suatu penelitian. Variabel dibedakan menjadi dua yaitu variabel bebas dan variabel terikat (Arikonto, 2006). Variabel dalam penelitian ini adalah sebagai berikut:

Variabel bebas (Independent variabel) dalam penelitian ini adalah :

$$
\begin{aligned}
& \mathrm{X}_{1}=\text { lahan } \\
& \mathrm{X}_{2}=\text { tenaga kerja } \\
& \mathrm{X}_{3}=\text { modal }
\end{aligned}
$$

Variabel terikat (dependent variable) dalam penelitian ini adalah :

$$
\mathrm{Y}=\text { Pendapatan }
$$

\section{Definisi Operasional}

1. Lahan $\left(\mathrm{X}_{1}\right)$ adalah merupakan tanah (tempat) yang digunakan untuk melakukan kegiatan usahatani. Indikator lahan yaitu :

- Kepemilikan

- Luas lahan $\left(\mathrm{m}^{2}\right)$

2. Tenaga kerja $\left(\mathrm{X}_{2}\right)$ adalah individu yang memiliki kemampuan bekerja dan tergolong dalam angkatan kerja, bersedia bekerja pada tingkat upah tertentu yang ditujukan untuk menghasilkan produksi.

Indikator tenaga kerja yaitu :

- Umur

- Pendidikan

- Pengalaman

- Jumlah tenaga kerja

3. Modal $\left(\mathrm{X}_{3}\right)$ adalah barang atau uang yang bersama-sama faktor produski-faktor produksi tanah dan tenaga kerja menghasilkan barangbarang baru yaitu dalam hal ini hasil pertanian. Indikator modal yaitu :

- Sumber pendanaan 
- Biaya produksi

4. Pendapatan (Y) adalah sejumlah uang yang diperoleh dari total penerimaan setelah dikurangi dengan biaya-biaya yang dikeluarkan selama proses produksi.

Indikator pendapatan yaitu :

- Jumlah produksi

- Harga penjualan

\section{Analisis Jalur (Path Analysis)}

Teknik analisa data yang yang digunakan dalam penelitian ini untuk mengetahui seberapa besar pengaruh lahan, tenaga kerja dan modal terhadap pendapatan petani adalah menggunakan Analisis Jalur (Path Analisis).

Menurut Sugiyono (2005:183) menyatakan bahwa "Analisis jalur digunakan untuk mengukur besarnya kontribusi atau pengaruh variabel bebas terhadap variabel terikat, baik pengaruh secara langsung maupun pengaruh secara tidak langsung melalui hubungan dengan variabel bebas lainnya".

\section{HASIL PENELITIAN PEMBAHASAN \\ Hasil Penelitian \\ Analisis Jalur}

Hasil dari uji validitas angket dan reliabilitas yang diperoleh bahwa setiap butir pertanyaan dinyatakan valid dan reliabel. Selanjutnya dilakukan perhitungan analisis jalur dan secara lengkap dapat dilihat pada lampiran. Berikut ini adalah tabel hasil penelitian analisis jalur dengan menggunakan program SPSS (Statistical Package for the Social Sciene) V.20,0 for Windows. Kerangka hubungan antara jalur $\left(\mathrm{X}_{1}\right.$, $\mathrm{X}_{2}, \mathrm{X}_{3}$ terhadap $\mathrm{Y}$ ) dapat dilihat melalui persamaan variabel sebagai berikut:

$$
\mathrm{Y}=\mathrm{P}_{\mathrm{Y}} \mathrm{X}_{1}+\mathrm{P}_{\mathrm{Y}} \mathrm{X}_{2}+\mathrm{P}_{\mathrm{y}} \mathrm{X}_{3} \varepsilon
$$

Untuk mengetahui koefisien

jalur dapat dilihat dari nilai beta pada tabel coefficient berikut:

Tabel 1. Coefficients ${ }^{\mathrm{a}}$

\begin{tabular}{|c|c|c|c|c|c|c|}
\hline \multirow{2}{*}{\multicolumn{2}{|c|}{ Model }} & \multicolumn{2}{|c|}{$\begin{array}{c}\text { Unstandardiz } \\
\text { ed } \\
\text { Coefficients }\end{array}$} & \multirow{2}{*}{$\begin{array}{c}\text { Standar } \\
\text { dized } \\
\text { Coeffici } \\
\text { ents } \\
\text { Beta }\end{array}$} & \multirow[t]{2}{*}{$\begin{array}{l}\mathrm{t} \\
\mathrm{B}\end{array}$} & \multirow[t]{2}{*}{ Sig. } \\
\hline & & B & $\begin{array}{l}\text { Std. } \\
\text { Error }\end{array}$ & & & \\
\hline \multirow{4}{*}{1} & $\begin{array}{l}\text { (Con } \\
\text { stant } \\
\text { ) }\end{array}$ & 4,112 & 925 & & $\begin{array}{r}4,44 \\
5\end{array}$ & ,000 \\
\hline & $\begin{array}{l}\text { laha } \\
\mathrm{n}\end{array}$ & ,416 & ,083 & ,481 & $\begin{array}{r}5,01 \\
4\end{array}$ & ,000 \\
\hline & $\begin{array}{l}\text { tena } \\
\text { ga } \\
\text { kerja }\end{array}$ & ,240 & ,055 & ,269 & $\begin{array}{r}4,33 \\
3\end{array}$ & ,000 \\
\hline & $\begin{array}{l}\text { mod } \\
\text { al }\end{array}$ & 249 & ,058 & ,368 & $\begin{array}{r}4,26 \\
7\end{array}$ & ,000 \\
\hline
\end{tabular}

a. Dependent Variable: pendapatan

Dari tabel 1. dapat diketahui masing-masing koefisien jalur dari setiap variabel, dan didapatkan persamaan sebagai berikut:

$$
Y=0,481 X_{1}+0,269 X_{2}+0,368+
$$

Dimana dalam mencari nilai $\mathrm{Py} \varepsilon_{1}$ dipergunakan rumus sebagai berikut:

$\mathrm{P}_{\mathrm{y}} \varepsilon_{1}=P_{y} \varepsilon_{1}=\sqrt{ } 1-R^{2}$ untuk mengetahui nilai $R^{2}$ dapat dilihat dari tabel 2. sebagai berikut:

Tebel 2. Model Summary

\begin{tabular}{|c|c|c|c|c|}
\hline Model & $\mathrm{R}$ & $\begin{array}{c}\mathrm{R} \\
\text { Square }\end{array}$ & $\begin{array}{c}\text { Adjusted } \\
\mathrm{R} \\
\text { Square }\end{array}$ & $\begin{array}{c}\text { Std. } \\
\text { Error of } \\
\text { the } \\
\text { Estimate }\end{array}$ \\
\hline 1 & $.936(\mathrm{a})$ & .872 & .867 & .922 \\
\hline
\end{tabular}

a. Predictors : (Constant), tenaga kerja, modal, lahan

Dari tabel tersebut diperoleh :

$$
\begin{aligned}
& R^{2} \quad=0,872 \\
& P_{Y} \varepsilon_{1}=\sqrt{ } 1-R^{2} \\
& P_{Y} \varepsilon_{1}=\sqrt{ } 1-0,872 \\
& P_{Y} \varepsilon_{1}=\sqrt{ } 0,128 \\
&=0,357
\end{aligned}
$$


ISSN: 1978-7057

Persamaan struktural untuk diagram jalur diatas akan menjadi:

$Y=0,481 X_{1}+0,269 X_{2}+0,368+0,357 \varepsilon$

Koefisien Determinasi

Determinan digunakan untuk mengetahui seberapa besar variabel independen mampu menjelaskan pengaruh variabel dependen. Dari tabel 4.20 dapat diketahui besarnya angka $R^{2}$ adalah 0,872 yang berarti variabel lahan, tenaga kerja dan modal menjelaskan pengaruh terhadap variabel pendapatan sebesar $87,2 \%\left(R^{2} \times 100 \% ; 0,872 \times 100 \%=\right.$ $87,2 \%)$ sedangkan sisanya $12,8 \%$ dijelaskan oleh variabel-variabel lain diluar model penelitian ini.

Uji Hipotesis

Pengaruh Lahan, Tenaga Kerja dan Modal Terhadap Pendapatan Secara Simultan (bersama-sama).

Untuk mengetahui apakah model regresi diatas sudah benar atau salah, diperlukan uji hipotesis. Uji hipotesis menggunakan angka $\mathrm{F}$ sebagimana tertera dalam tabel berikut ini :

Tabel 3. ANOVA (b)

\begin{tabular}{|c|c|c|c|c|c|c|}
\hline \multicolumn{2}{|c|}{ Model } & \multirow{2}{*}{$\begin{array}{r}\begin{array}{c}\text { Sum of } \\
\text { Square } \\
\text { S }\end{array} \\
274.48 \\
8 \\
\end{array}$} & \multirow{2}{*}{$\begin{array}{r}\text { df } \\
3\end{array}$} & \multirow{2}{*}{$\begin{array}{c}\begin{array}{c}\text { Mean } \\
\text { Squar } \\
\text { e }\end{array} \\
91.496\end{array}$} & \multirow{2}{*}{$\begin{array}{c}\mathrm{F} \\
\\
107 . \\
555\end{array}$} & \multirow{2}{*}{$\begin{array}{r}\text { Sig. } \\
\\
.000 \\
\text { (a) }\end{array}$} \\
\hline \multirow{3}{*}{1} & $\begin{array}{l}\text { Regre } \\
\text { ssion }\end{array}$ & & & & & \\
\hline & $\begin{array}{l}\text { Resid } \\
\text { ual }\end{array}$ & 39.132 & 66 & .851 & & \\
\hline & Total & $\begin{array}{r}13.62 \\
0\end{array}$ & 69 & & & \\
\hline
\end{tabular}
berikut :

Hipotesisnya berbunyi sebagai

- $\mathrm{H}_{0}$ : Tidak ada hubungan linier antara lahan, tenaga kerja dan modal dengan pendapatan.

- $\mathrm{H}_{1}$ : Ada hubungan linier antara lahan, tenaga kerja dan modal dengan pendapatan.
Pengujian dapat dilakukan dengan dua cara :

- Pertama, dengan cara membandingkan besarnya angka $\mathrm{F}$ penelitian dengan $\mathrm{F}$ tabel.

- Kedua, dengan cara membandingkan besarnya angka taraf signifikansi (sig) hasil penghitungan dengan taraf signifikansi 0,05 (5\%).

Menggunakan cara pertama atau membandingkan besarnya angka $\mathrm{F}$ penelitian dengan $\mathrm{F}$ tabel. Caranya sebagai berikut :

Pertama : Menghitung F penelitian

F penelitian dari SPSS didapatkan sebesar 107,555

Kedua : Menghitung $\mathrm{F}$ tabel dengan ketentuan sebagai berikut :

Taraf signifikansi 0,05 dan Derajat Kebebasan (DK) 67. Dengan ketentuan tersebut, diperoleh angka $\mathrm{F}$ tabel sebesar 1,994.

Ketiga : Menentukan kriteria uji hipotesis sebagai berikut.

Jika $\mathrm{F}$ penelitian $>\mathrm{F}$ tabel maka $\mathrm{H}_{0}$ ditolak dan $\mathrm{H}_{1}$ diterima.

Jika Jika $\mathrm{F}$ penelitian $<\mathrm{F}$ tabel maka $\mathrm{H}_{0}$ diterima dan $\mathrm{H}_{1}$ ditolak.

Keempat : Mengambil keputusan

Dari hasil penghitungan didapatkan angka $\mathrm{F}$ penelitian sebesar $107,555>\mathrm{F}$ tabel sebesar 1,994. Maka $\mathrm{H}_{0}$ ditolak dan $\mathrm{H}_{1}$ diterima. Artinya, ada hubungan linier antara lahan, tenaga keja dan modal terhadap pendapatan. Dengan demikian, model regresi diatas sudah layak atau benar. Kesimpulannya adalah bahwa lahan, tenaga kerja dan modal secara simultan mempengaruhi pendapatan. Besarnya pengaruah adalah $87,2 \%$. Besarnya pengaruh variabel lain diluar model regresi tersebut dihitung 
dengan rumus : $1-r^{2}$ atau $1-0,872=$ 0.128 atau sebesar $12,8 \%$.

Menggunakan cara kedua atau membandingkan besarnya angka taraf signifikansi (sig) penelitian dengan taraf signifikansi sebesar 0,05. Dengan kriteria sebagai berikut :

Jika sig penelitian $>0,05$ maka $\mathrm{H}_{0}$ ditolak dan $\mathrm{H}_{1}$ diterima sedangkan jika sig penelitian $<0,05$ maka $\mathrm{H}_{0}$ diterima dan $\mathrm{H}_{1}$ ditolak.

Berdasarkan penghitungan angka signifikansi sebesar $0,00<0,05$ maka $\mathrm{H}_{0}$ ditolak dan $\mathrm{H}_{1}$ diterima. Artinya, ada hubungan linier antara lahan, tenaga kerja dan modal dengan pendapatan.

\section{Pengaruh Lahan, Tenaga Kerja dan Modal Terhadap Pendapatan Secara Parsial (terpisah)}

Untuk melihat besarnya pengaruh variabel lahan, tenaga kerja dan modal terhadap pendapatan secara parsial digunakan uji $\mathrm{T}$, sedangkan untuk melihat besarnya angka Beta atau Standardized Coefficients dapat dilihat pada tabel dibawah ini :

Tabel 4. Coefficients ${ }^{\mathrm{a}}$

\begin{tabular}{|c|c|c|c|c|c|c|}
\hline \multirow{2}{*}{\multicolumn{2}{|c|}{ Model }} & \multicolumn{2}{|c|}{$\begin{array}{c}\text { Unstandardized } \\
\text { Coefficients }\end{array}$} & \multirow{2}{*}{$\begin{array}{c}\begin{array}{c}\text { Standar } \\
\text { dized } \\
\text { Coefficie } \\
\text { nts }\end{array} \\
\text { Beta }\end{array}$} & \multirow[t]{2}{*}{$\mathrm{t}$} & \multirow[t]{2}{*}{ Sig. } \\
\hline & & B & $\begin{array}{l}\text { Std. } \\
\text { Error }\end{array}$ & & & \\
\hline \multirow{4}{*}{1} & $\begin{array}{l}\text { (Consta } \\
\text { nt) }\end{array}$ & 4,112 & ,925 & & 4,445 & ,000 \\
\hline & Lahan & ,416 & ,083 & ,481 & 5,014 &, 000 \\
\hline & $\begin{array}{l}\text { tenaga } \\
\text { kerja }\end{array}$ & ,240 & ,055 & ,269 & 4,333 & ,000 \\
\hline & Modal & ,249 & ,058 & ,368 & 4,267 &, 000 \\
\hline
\end{tabular}

a. Dependent Variable: pendapatan

\section{Hubungan Lahan dan Pendapatan}

Untuk melihat apakah ada hubungan linier antara lahan dan pendapatan, kita dapat melakukan langkah-langkah analisis sebagai berikut :
Pertama : Menentukan hipotesis $\mathrm{H}_{0}$ : Tidak ada hubungan linier antara lahan dengan pendapatan

$\mathrm{H}_{1}$ : Ada hubungan linier antara lahan dengan pendapatan

Kedua: Menghitung besarnya angka t penelitian

Hasil penghitungan SPSS diperoleh angka t penelitian sebesar 5,014

Ketiga : Menghitung besarnya angka $t$ tabel dengan ketentuan sebagai berikut :

Taraf signifikansi 0,05 dan Derajat Kebebasan (DK) 67. Dari ketentuan tersebut diperoleh angka $\mathrm{t}$ tabel sebesar 1,994

Keempat: Menentukan kriteria uji hipotesisnya sebagai berikut :

Jika $\mathrm{t}$ penelitian $>\mathrm{t}$ tabel maka $\mathrm{H}_{0}$ ditolak dan $\mathrm{H}_{1}$ diterima. Jika Jika $\mathrm{t}$ penelitian $<\mathrm{t}$ tabel maka $\mathrm{H}_{0}$ diterima dan $\mathrm{H}_{1}$ ditolak.

Kelima : Mengambil keputusan Dari hasil penghitungan, diperoleh angka $\mathrm{t}$ penelitian sebesar 5,014 >t tabel sebesar 1,994 sehingga $\mathrm{H}_{0}$ ditolak dan $\mathrm{H}_{1}$ diterima. Artinya, ada hubungan linier antara lahan dengan pendapatan. Kemudian besarnya pengaruh lahan terhadap pendapatan adalah 0,429 atau $42,9 \%$.

\section{Hubungan Tenaga Kerja dan Pendapatan}

Dari hasil penghitungan, diperoleh angka $t$ penelitian sebesar 4,333 > t tabel sebesar 1,994 sehingga $\mathrm{H}_{0}$ ditolak dan $\mathrm{H}_{1}$ diterima. Artinya, ada hubungan linier antara tenaga kerja dengan pendapatan. Kemudian besarnya pengaruh tenaga kerja terhadap pendapatan adalah 0,152 atau $15,2 \%$.

\section{Hubungan Modal dan Pendapatan}


Dari hasil penghitungan, diperoleh angka t penelitian sebesar 4,267 > t tabel sebesar 1,994 sehingga $\mathrm{H}_{0}$ ditolak dan $\mathrm{H}_{1}$ diterima. Artinya, ada hubungan linier antara modal dengan pendapatan. Kemudian besarnya pengaruh modal terhadap pendapatan adalah 0,291 atau 29,1\%.

\section{Korelasi Antar Variabel Bebas}

Untuk mengetahui korelasi antara lahan, tenaga kerja dan modal dapat dilihat pada tabel dibawah ini :

\section{Tabel 5. Correlations}

\begin{tabular}{|c|c|c|c|c|}
\hline & & Lahan & $\begin{array}{l}\text { Tenaga } \\
\text { kerja }\end{array}$ & Modal \\
\hline \multirow{3}{*}{ Lahan } & $\begin{array}{l}\text { Pearson } \\
\text { Correlation }\end{array}$ & 1 &, $474\left({ }^{* \star}\right)$ &, $774\left(^{* *}\right)$ \\
\hline & Sig. (2-tailed) & & 001 &, 000 \\
\hline & $\mathrm{N}$ & 70 & 70 & 70 \\
\hline \multirow{3}{*}{$\begin{array}{l}\text { Tenaga } \\
\text { kerja }\end{array}$} & $\begin{array}{l}\text { Pearson } \\
\text { Correlation }\end{array}$ &, $474\left(^{\star *}\right)$ & 1 & , 199 \\
\hline & Sig. (2-tailed) & ,001 & & ,167 \\
\hline & $\mathrm{N}$ & 70 & 70 & 70 \\
\hline \multirow{3}{*}{ Modal } & $\begin{array}{l}\text { Pearson } \\
\text { Correlation }\end{array}$ &, $774\left({ }^{* *}\right)$ & , 199 & 1 \\
\hline & Sig. (2-tailed) &, 000 & ,167 & \\
\hline & $\mathrm{N}$ & 70 & 70 & 70 \\
\hline
\end{tabular}

\section{Korelasi Antara Lahan dan Tenaga Kerja}

Berdasarkan perhitungan diperoleh angka korelasi antara variabel lahan dan modal sebesar 0,474 . Untuk menafsir angka tersebut digunakan kriteria sebagai berikut :

- $0-0,25$ : korelasi sangat lemah (dianggap tidak ada)

- $>0,25-0,5$ : korelasi cukup

- $>0,5-0,75$ : korelasi kuat

- $>0,75-1$ : korelasi sangat kuat

Korelasi sebesar 0,474

mempunyai maksud hubungan antara variabel lahan dan tenaga kerja cukup dan searah (karena hasilnya positif). Searah artinya jika lahan luas maka tenaga kerja tinggi. Korelasi dua variabel bersifat signifikan (sig) < $0,05$. Jika angka signifikan ( $\mathrm{sig})<$ 0,05 maka hubungan kedua variabel signifikan. Sebaliknya, jika angka signifikan (sig) $>0,05$ maka hubungan kedua variabel tidak signifikan.

\section{Korelasi Antara Lahan dan Modal Berdasarkan perhitungan} diperoleh angka korelasi antara variabel lahan dan modal sebesar 0,774. Korelasi sebesar 0,774 mempunyai maksud hubungan antara variabel lahan dan modal adalah sangat kuat dan searah (karena hasilnya positif). Searah artinya jika lahan luas maka modal tinggi. Korelasi dua variabel bersifat signifikan karena angka signifikansi sebesar $0,000<0,05$.

\section{Korelasi Antara Tenaga Kerja dan Modal}

Berdasarkan perhitungan diperoleh angka korelasi antara variabel tenaga kerja dan modal sebesar 0,199. Korelasi sebesar 0,199 mempunyai maksud hubungan antara variabel tenaga kerja dan modal adalah sangat lemah dan searah (karena hasilnya positif). Korelasi dua variabel bersifat signifikan karena angka signifikansi sebesar $0,000<$ 0,05 .

\section{Pengaruh Langsung dan Tidak Langsung}

Untuk menghitung pengaruh langsung antara variabel bebas dengan variabel terikat digunakan rumus $\mathrm{P}_{\mathrm{Yxi}} \mathrm{x} \mathrm{P}_{\mathrm{Yxi}}$, sedangkan ntuk menghitung pengaruh tidak langsung digunakan rumus $\mathrm{P}_{\mathrm{Yxi}} \mathrm{X} \mathrm{r}_{\mathrm{xixi}} \times \mathrm{P}_{\mathrm{Yxi}}$.

1) Pengaruh Lahan $\left(X_{1}\right)$ 
- Pengaruh langsung $=23,1 \%$

- Pengaruh tidak langsung melalui $\mathrm{X}_{2}=6,1 \%$

- Pengaruh tidak langsung melalui $\mathrm{X}_{3}=13,7 \%$

2) Pengaruh Tenaga Kerja $\left(X_{2}\right)$

- Pengaruh langsung $=7,2 \%$

- Pengaruh tidak langsung melalui $\mathrm{X}_{1}=6,1 \%$

- Pengaruh tidak langsung melalui $\mathrm{X}_{3}=1,9 \%$

3) Pengaruh Modal $\left(X_{3}\right)$

- Pengaruh langsung $=13,5 \%$

- Pengaruh tidak langsung melalui $\mathrm{X}_{1}=13,7 \%$

- Pengaruh tidak langsung melalui $\mathrm{X}_{2}=1,9 \%$

4) Pengaruh variabel lain $(\varepsilon)=1$ $\mathrm{R}^{2}$ atau $\left(\mathrm{P}_{\mathrm{x} 4 \varepsilon}\right)^{2}=12,8 \%$

Tabel 6. Pengaruh Langsung dan Tidak Langsung

\begin{tabular}{|c|c|c|c|c|c|}
\hline Variabel & Langsung & $\mathrm{X}_{1}$ & $\overline{X_{2}}$ & $X_{3}$ & Total \\
\hline $\mathrm{X}_{1}$ & $23,1 \%$ & $0,00 \%$ & $6,1 \%$ & $13,7 \%$ & $42,9 \%$ \\
\hline $\mathrm{X}_{2}$ & $7,2 \%$ & $6,1 \%$ & $0,00 \%$ & $1,9 \%$ & $15,2 \%$ \\
\hline $\mathrm{X}_{3}$ & $13,5 \%$ & $13,7 \%$ & $1,9 \%$ & $0,00 \%$ & $29,1 \%$ \\
\hline \multicolumn{5}{|c|}{$\begin{array}{r}\text { Total pengaruh langsung dan tidak langsung } \\
\text { variabel } X_{1}, X_{2}, X_{3}\end{array}$} & $87,2 \%$ \\
\hline \multicolumn{5}{|c|}{ Pengaruh variabel lain } & $12,8 \%$ \\
\hline & & & & Total & $100 \%$ \\
\hline
\end{tabular}

Dari tabel diatas dapat diketahui pengaruh langsung dan tidak langsung dari variabel lahan $\left(\mathrm{X}_{1}\right)$, tenaga kerja $\left(\mathrm{X}_{2}\right)$ dan modal $\left(\mathrm{X}_{3}\right)$ sebesar $87,2 \%$ sedangkan pengaruh variabel lain sebesar $12,8 \%$.

\section{Pembahasan Hasil Penelitian}

Data dalam penelitian ini diperoleh dengan cara menyebarkan kuesioner kepada petani tanaman hias di Desa Bangun Sari Kecamatan Tanjung Morawa Kabupaten Deli
Serdang dan mengumpulkannya kembali. Penelitian ini bertujuan untuk mengetahui pengaruh lahan, tenaga kerja dan modal terhadap pendapatan petani tanaman hias di Desa Bangun Sari Kecamatan Tanjung Morawa Kabupaten Deli Serdang. Analisis yang digunakan dalam penelitian ini adalah analisis jalur (Path Analysis). Setelah dilakukan analisis data diperoleh persamaan :

$Y=0,481 X_{1}+0,269 X_{2}+0,368 X_{3}+$ $\mathbf{0 , 3 5 7 \varepsilon}$

Berdasarkan hasil penelitian yang dilakukan terhadap 30 petani tanaman hias di Desa Bangun Sari Kecamatan Tanjung Morawa Kabupaten Deli Serdang, diperoleh nilai $\mathrm{R}^{2}$ sebesar 0,872 yang berarti variabel lahan, tenaga kerja dan modal menjelaskan pengaruh terhadap variabel pendapatan sebesar $87,2 \%\left(\mathrm{R}^{2} \times 100 \% ; 0,872 \times 100 \%=\right.$ $87,2 \%)$ sedangkan sisanya $12,8 \%$ ( $100 \%$ - 87,2\%) dipengaruhi oleh variabel lain diluar model penelitian ini. Setelah dilakukan uji hipotesis secara simultan $(\mathrm{Uji}-\mathrm{F})$, variabel lahan, tenaga kerja dan modal secara bersama-sama berpengaruh signifikan terhadap pendapatan. Setelah dilakukan uji hipotesis secara parsial $(\mathrm{Uji}-\mathrm{t})$, variabel lahan, tenaga kerja dan modal secara terpisah berpengaruh signifikan terhadap pendapatan.

\section{PENUTUP}

Berdasarkan hasil analisis data penelitian dan pembahasan yang telah dilakukan dalam penelitian ini, maka terdapat beberapa kesimpulan sebagai berikut :

1. Lahan berpengaruh positif dan signifikan terhadap pendapatan 
JURNAL PLANS

Penelitian Ilmu Manajemen \& Bisnis

ISSN: 1978-7057

petani di Desa Bangun Sari Kecamatan Tanjung Morawa Kabupaten Deli Serdang.

2. Tenaga kerja berpengaruh positif dan signifikan terhadap pendapatan petani di Desa Bangun Sari Kecamatan Tanjung Morawa Kabupaten Deli Serdang.

3. Modal berpengaruh positif dan signifikan terhadap pendapatan petani di Desa Bangun Sari Kecamatan Tanjung Morawa Kabupaten Deli Serdang.

4. Lahan, tenaga kerja dan modal berpengaruh positif dan signifikan baik secara simultan maupun secara parsial terhadap pendapatan petani di Desa Bangun Sari Kecamatan Tanjung Morawa Kabupaten Deli Serdang.

\section{DAFTAR PUSTAKA}

Ahmadi. 2001. Ilmu Usahatani. Penebar Swadaya : Jakarta

Ahyari. 2004. Pengantar Ekonomi Pertanian. LP3ES : Jakarta

Arikunto, S. 2002. Prosedur Penelitian Suatu Pendekatan Praktek. PT Rineka Cipta : Jakarta.

Azwar. 2003. Metode Skala Pegukuran VariabelVariabel Penelitian. Alfabeta : Bandung.

Daniel. 2005. Prinsip-Prinsip Dasar Ekonomi Pertanian. PT. Raja Grafindo Persada : Jakarta.

Hernanto, Fadholi. 2002. Ilmu Usahatani. Penebar Swadaya: Jakarta.

Khazanani, Annora. 2013. Analisis Faktor-Faktor Yang Mempengaruhi Pendapatan
Petani Cabai di Desa Gondosuli Kecamatan Bulu Kabupaten Temanggung. Skripsi. Fakultas Pertanian, Universitas Semarang.

Mei, Anggun. 2010. Analisis FaktorF

aktor Yang Mempengaruhi Tingkat Pendapatan Petani Jeruk di Desa Sukomoro Kabupaten Magetan. Skripsi. Fakultas Pertanian, Universitas Semarang.

Moehar. 2001. Pengantar Ekonomi Pertanian. Bumi Aksara : Jakarta.

Mubyarto. 2000. Pengantar Ekonomi Pertanian. LP3ES : Jakarta

Pasaribu, Rivandy. 2012. Pengaruh Faktor-Faktor Produksi Terhadap Pendapatan Petani Tebu di Desa Kwala Begumit Kecamatan Stabat Kabupaten Langkat. Skripsi. Faklutas Pertanian, Universitas Sumatera Utara.

Rahardi. 2006. Agribisnis Tanaman Buah. Penebar Swadaya : Jakarta

Riduwan, Akdon. 2007. Metode Skala Pegukuran VariabelVariabel Penelitian. Alfabeta : Bandung

Siahaan, Freddy. 2012. Pengaruh Faktor-Faktor Produksi Terhadap Pendapatan Petani Kopi di Desa Tampahan Kabupaten Toba Samosir. Fakultas Pertanian, Universitas Sumatera Utara.

Soekartawi. 2002. Prinsip-Prinsip Dasar Ekonomi Pertanian. PT. Raja Grafindo Persada : Jakarta

Sugiyanto, Catur. 2003. Ekonomi Mikro. BPFE : Yogyakarta 
JURNAL PLANS

Penelitian Ilmu Manajemen \& Bisnis

ISSN: 1978-7057

Sugiono. 2002. Metode Penelitian Bisnis. Alfabeta : Bandung

Suhadi. 2002. Pengantar Ekonomi Pertanian. Bumi Aksara : Jakarta.

Sukarno, Cahyo. 2010. Pengaruh Modal, Tenaga Kerja dan Lahan Terhadap Pendapatan Petani Jambu Air Varietas Delima di Kabupaten
Demak. Skripsi. Fakultas Pertanian, Universitas Semarang.

Suratiah, Ken. 2002. Ilmu Usahatani. Penebar Swadaya : Jakarta

Tohir, A, Kaslan. 2001. Seuntai Pengetahuan Usahatani Indonesia. Rineka Cipta : Jakarta 